\title{
The Postmodern Thought of Michel Foucault Related to Structuralism
}

\author{
Kushtrim Ahmeti
}

Faculty of Philosophy, State University of Tetova; PHD candidate in Philosophy; kushtrim.ahmeti@unite.edu.mk

\section{Doi:10.5901/mjss.2016.v7n2s1p354}

\begin{abstract}
Michel Foucault is the emblematic figure of French postmodernism which is characterized by an originality in his ideas, who made an extraordinary contribution with his work. He used to call himself a product of modern tradition although his works represented a comprehensive and original critique precisely of this way of thinking. He is an ever actual philosopher which drew scientific and intellectual attention from early days. With his ideas he wanted to make a clear distinction from structuralism and other previous tendencies by joining the voice of other postmodern theorists who were attempting to show as inadequate and overly humanizing the alternatives which were offered by modern philosophical systems. In this paper we will review his thought related to structuralism as a theoretical and philosophic direction with which he was usually identified while he categorically denied it. We will also analyze the reasons why did it come to identification and equivalence of Foucault with structuralism.
\end{abstract}

Keywords: Postmodernism, structuralism, Foucault, relation

\section{Introduction}

The thought that Foucault is an eclectic thinker is ubiquitous, where the impact of many sources and issues are present without specially focusing on any of them.

Although he had the decisive influence on the postmodern theory, it is nevertheless thought that he successfully combined the premodern, modern and postmodern.

There are opinions that Foucault should be considered as poststructuralist but not a postmodernist as well, since he was always concerned about the other, which was a victim of the consequences of the normalizing and disciplinary power.

There is a rich variety of topics in the works of Foucault: from his early interests in psychology and madness, through the birth of modern medicine and human sciences, to the analysis of disciplinary forms of the history of sexuality.

Nonetheless the two dominating issues of his interest are: submission of conditions of representing the contemporary rationality, especially in human sciences and understanding the complex intertwining between knowledge and power (Weeks, 1982).

\subsection{The aim of the study}

The aim of this study is to determine the difference between the postmodern thought of Michel Foucault and the structuralist tendency, dominating in the philosophy of that time. In fact, with his ideas, he wanted to make a clear differentiation from structuralism and other precursory tendencies, joining this way the voice of other postmodern theorists which attempted to show as very humanizing the alternatives offered by theretofore modern philosophic systems.

\subsection{The objectives of the study}

The objective of this study is to explain certain research questions, from Foucault's perspective, such as:

- What are the differing characteristics of Foucault's philosophy in relation to structuralism?

Michel Foucault is the emblematic figure of French postmodernism as well, who, with his ideas, wanted to make a clear differentiation from structuralism, by supporting this way the other postmodern theorists that considered inadequate the alternatives offered by modern philosophic systems.

- Which are the reasons Michel Foucault refused to be called a structuralist?

Michel Foucault categorically denied every relation with structuralism, by opposing Sartre as well, in his 
attempt to categorize him with Lévi-Strauss, Althusser, Dumézil, by declaring that "we haven't noticed that such a unity exists".

- Is there a relation between structuralism and Foucault's thought?

Although he publicly reacted against the equivalence with structuralism, yet there were such appraisals that did not consider them as incidental: what joined Foucault and structuralism was the desire to suppress the subjective consciousness and instead to research "the positive unconscious knowledge", the hidden and structured imperative such as language, where the social forms are built.

\subsection{Research methodology}

By the hermeneutic interpretation used in this research we aim to focus on the issue of meaning interpretation, a typical qualitative interpretation which is based on the assertion that by every interpretation, the researcher constitutes reality since it is more than clear that meanings can be interpreted from certain perspectives, practices, points, regardless of whether it is about personal views related to gathered data from subjects included in the research.

The analysis and interpretation will be conducted through the technique of content analysis - data reduction by systematic categorization-identification and the objective of characteristics of messages given before or the technique of reducing any kind of qualitative material in order to identify certain consistent meanings.

\section{Foucault's Classification in Structuralism and His Objections}

Michel Foucault categorically denied every relation to structuralism by opposing different classifications that listed him among structuralists:

"In France, some half-witted 'commentators' persist in labeling me a 'structuralist'. I have been unable to get it into their tiny minds that I have used none of the methods, concepts, or key terms that characterize structural analysis" (Foucault, 1973).

In this direction he opposed Sartre as well, in his attempt to place him at the same categorization with LéviStrauss, Althusser, Dumézil, by declaring that "we haven't noticed such a unity exists".

In the conclusion of "The archaeology of knowledge" he will write: "So I did not wish to carry the structuralist enterprise beyond its legitimate limits. And you must admit that I never once used the word 'structure' in 'The order of things'" (Foucault, 2002).

While in "Answer to a question" he will determine the archaeological approach by clearly dividing it from the structuralist one: "To investigate not the laws of construction of discourse as is done by those who use structural methods, but its conditions of existence" (Foucault, 1968), while in a footnote of the same work he asks "Shall I once more specify that I am not something that is called structuralist?".

"It is up to those who use the same label 'structuralist' to refer to diverse works to say to what extent we are structuralists. You know the riddle: what is the difference between Bernard Shaw and Charlie Chaplin? There is no difference, because they both have beards, except for Chaplin, of course! (Foucault, 1969).

Even Claude Lévi-Straus, the well known representative of structuralism considered that Foucault was right when refusing this equivalence since his works were by no means close to structuralism and that the whole quarrel about a group of researchers was a fashionable but yet a temporary phenomenon.

In another case he will name it an imported movement by the east through Jacobson who was a Russian and formalists and that the whole Stalinist tradition had managed to oppress it precisely at the place where it was created.

"When in 1968 in Hungary, he went to lecture, everything went great, there were many listeners, until one day he wanted to talk about structuralism. The rector of the university said this lecture should be definitely held in his office, in front of a limited group because it is very difficult for students. What has prompted this much fear of that word, of those topics, of that idea was Foucault wondering" (Eribon, 2014).

This persistent refusal toward structuralism is probably primarily related to what had Dumézil done in the early 60s, with a desire to reformulate his theoretical approach in a new context and the Althusser's approach in early 70s which is related to the general politicization after 1968, when, joined by many others, they left structuralism in order to respond to the voice of the street, starting from Deleuze, who from the Logic of understanding will pass on to Anti - Oedipus, twisting his viewpoint in structural psychoanalysis, to Foucault who by a radical movement also passed from "The archaeology of knowledge" to the "Discipline and punish" (Eribon, 2014).

"Structuralism, from one side, is a productive method on specific fields such as linguistics, history of religions or ethnology, while on the other side stands structuralism which would be the activity by which the theorists, not specialists, 
would try to define the factual relations which perhaps exist between this and that cultural element in our culture, of this or that science, this practical and that theoretical domain and so on. In other words, the mediator would be a type of generalized structuralism but not a measured structuralism of a specific scientific field. It would also be the structuralism that would be concerned with our culture, our world today, the set of practical or theoretical relations which determine our modernity. In this, structuralism would be valued as a philosophical activity is we accept that the role of philosophy is diagnosis. While the structuralist philosopher would be the one who diagnoses what is today (Foucault, 2001).

To respond to all wrong readings and avoid misunderstandings and specify notions, discursive establishments by limiting them with structuralism, Foucault wrote "The Archaeology of knowledge" published in 1969.

"To explain what I have wanted to do in previous books in which many issues have remained uncertain. Not only that, not exactly that, but by going further, to turn back, as a spiral turn, further than how I have been treated, to say from where I have talked, to mark the space that enables these researches, and other, that might never appear; in short, that the meaning of that word, archaeology, which I left empty (...). The sphere of spoken words, that is what we call archive; archaeology is destined to analyze" (Foucault, 2002).

While in 1972, in the new edition of "The birth of the clinic" he will also make some lexical reorientations; therefore the sentence "Here we wanted to prove the structural analysis of a distinguished medical experience in an era..." will become "Here we wanted, in an analysis of a type of discourse - medical experience discourse - in an era..." by erasing the notion structural analysis even in the following pages (Foucault, 1963).

Foucault was not called a structuralist only by his opponents. This way, Deleuze in an article published in 1967, trying to answer what is structuralism, among the representatives, except Lévi - Straus, Lacan, Althusser, he mentions Foucault as well and defines a certain number of formal criteria, which enable that in the parts or heterogeneous orientation and preoccupation to find guidelines on which the affiliation of this movement is based.

Except the distinction with structuralism, with Foucault is constantly present the other tendency of reviewing previous positions and attitudes, expressed in the frames of his works. Thus in 1961 he will declare that "History of madness' is a history of change, while 'Words and things' is a history of similarities and identities"

\section{Foucault's Relation to Structuralism}

Although he reacted publicly against the equivalence to structuralism, there were still such evaluations that did not consider them as accidental. Therefore it was considered that the young called him a structuralist to honor him, as they had done with Sartre quarter of a century ago with the modern word of that time, existentialist.

Precisely at the group of works called first-circle group "Mental illness and psychology" (1954), "The birth of the clinic: An archaeology of medical perception" (1963) can be found a stream of thoughts which classify him among leaders of structuralist thought.

Even in the publication titled "Answering a Question", Foucault attempts to modify his position of the time he wrote "Words and things", by which he tacitly accepts some of the comments and criticism given on this work.

It is about the issue: Can the thought that precedes the obligation to the system and discontinuity in the history of the spirit, eliminate every basis for a progressive political intervention? (Foucault, 1968).

$\mathrm{He}$ in his response, he initially emphasizes that he is a pluralist, and that the notion system, when it comes to his philosophy, must be used in plural, and always leaning towards individualization of discourse which according to him "is not provided by any formal structure, nor coherent architecture of notions" (Foucault, 1968). And in achieving this goalindividualization of discourse, he uses three measures on the basis of which is seen that "episteme is not any kind of big theory that is present in the underground, but a space of distribution, dissemination" (Foucault, 1968).

It is also a comprehensive thought that the wish to oppress the subjective consciousness joined him to structuralism, that instead of it to research "the positive unconscious knowledge", the hidden and structured imperatives such as the language where social forms are built.

However, unlike the structuralists who claimed to have discovered the system that can scientifically explain everything, starting from the structure of the family to the comprehension of texts, Foucault poses the question how is this intellectual system possible and what are its consequences; a question posed also in the case of psychoanalysis and Marxism, systems which shaped him intellectually but he wanted to reject their scientific allegations (Weeks, 1982).

When "Madness and unreason" was published, Michel Serre qualified it as descriptions of variations of structure, of the structure of separation, relationships, union, foundation, reciprocity, exclusion; since, according to him the history of madness will never be understood as genesis of psychiatric categories, as inquiries, in the period of classicism, for the first positive allusive ideas (Serre, 1962).

In fact, for both directions, the common things were only the denials that between things and consciousness exists 
a special treatment that saves the sovereignty of the subject, a lack of transparency which goes further than the bad faith and ambiguity were precious to the Sarterean subtlety.

On the other side, Jean Piaget will call him "a structuralist without a structure" exactly for the fact that he developed his thoughts about the main issues structuralism was dealing with without even using the structuralist method, in fact Piaget, by structure signified a system, coherence... totality which is not identical to the amount of its parts and the determination of structure in the human life phenomena means re-finding of such totalities, unities, objectively, because structure by definition is a closed system, self-sufficient, which means it will free them from subjectivities.

Even the axiom of structuralism is in this spirit: "To reach reality, experience should be refused, since this is the only way to get saved from the tragic risk of subjectivism".

Therefore, by eliminating the "tragic risk of subjectivism", consequently, the other great risk of philosophy of consciousness is eliminated, the one of freedom in general and freedom of will, because in the dark places of unconsciousness this issue is not submitted, since freedom by definition is a conscious choice while the forms which are unconsciously imposed with different random contents, same for all souls, according to Lévi-Strauss for all times and by Foucault at least for one era.

These forms of "wild thought" as Lévi-Strauss call them, are forms of the natural and universal human thoughts which are accomplished in a limited number, unconsciously, while the non analytical but mandatory processes such as imagination, inventiveness, inspiration, passion represent only a superficial tyranny, games on depths. (The wild thought...).

Whereas, when Gaston Bachelard read his first book, he wrote to Foucault: "Sociologists go far away to explore foreign tribes and people. You tell them that we are a mix of the wilds. You are a true researcher" (Foucault, 1985).

Starting from the essential notions, there are substantial distinctions between him and Levi - Strauss, as one of the emblematic representatives of structuralism. Thus, unlike the evident universal human nature so much proclaimed by Lévi-Strauss, Foucault calls for its diffraction by insisting that there are no permanent elements of the human spirit and that the concept human itself is false and inexistent.

However he was impressed by the success of Claude Lévi-Strauss, and he did not hesitate to declare that he admired the success he had achieved by destroying the borders which were separating the specialized audience which reads university works and the wide cultural audience (Eribon, 2014).

\section{Conclusion}

We can conclude that Foucault's identification to structuralism was as a consequence that every thought which was separated from Marxism, phenomenology and philosophy of consciousness was easily starting to be considered as a structuralist.

"The structure and discourse were neither Husserl's, or Marx's or humanism's; it was sufficient for you round 1970 to be seen by the historians of society and philosophers of consciousness and subject: Foucault and structuralism, same heresy. But for the others it was exciting that something new emerges" (Veyne, 2008).

The ubiquitous conclusion is that in Foucault exists an amalgam between the structuralist - linguistic thesis in one side and Heideggeranism and Nietzcheanism in the other side, which are not present in Lévi-Strauss thought.

No matter how different their worlds are, yet we can say that they are based on quite similar postulates: the primate of structuralist linguistics, the indifferent attitude towards semantics, disregard of conscious intentions of speaking subjects.

Even to Foucault everything important is in the unconscious, because for him, structuralism is an attempt to shape a content that is beyond awaken and concerned consciousness of the modern knowledge, calling into question our culture, denying humanity and philosophy on which it is based.

We need to emphasize that structuralism's unconsciousness is a pure form, always true, a super rational instrument of classification, an intellect that is always identical to itself, for which everything is an abstract relation, distinguishing from that of Freud which is created by pressure of contents which with their deformed or reformed shape tend to return to consciousness.

\section{References}

Eribon, D. (2014). Michel Foucault (Mišel Fuko). Beograd: Karpoš.

Foucault, M. (2002). Archaeology of Knowledge. London and New York: Psychology Press.

Foucault, M. (2001). The Essential Works of Foucault 1954-1984, vol.I (Dits et écrits I). Paris: Gallimard. 
Foucault, M. (1969). Birth of a world (La naissance d'un monde). Le Monde .

Foucault, M. (1963). Birth of the Clinic: An Archaeology of Medical Perception (Naissance de la clinique. Une archéologie du regard medical). Paris: PUF.

Foucault, M. (1968). Responding to a question (Réponse à une question). Esprit no. 5.

Serre, M. (1962). The geometry of the incommunicable: madness ( Géométrie de la folie) Mercure de France.

Veyne, P. (2008). Foucault, His Thought, His Character (Foucault, Sa pensé, sa personne),. Paris: Albin Michel.

Weeks, J. (1982). Foucault for Historians. History Workshop Journal 14 , 106-119. 